\title{
Socio-economic Issues Related to Immigrants in American Political and Election Discourses
}

\author{
Mubarak Altwaiji $1^{1}$ \& Muna Telha ${ }^{2}$ \\ ${ }^{1}$ Faculty of Education and Arts, Northern Border University, Kingdom of Saudi Arabia \\ ${ }^{2}$ Faculty of Business Administration, Northern Border University, Kingdom of Saudi Arabia \\ Correspondence: Mubarak Altwaiji, Northern Border University, Kingdom of Saudi Arabia. E-mail: \\ mubarak2006ye@gmail.com or mubarak.saif@nbu.edu.sa
}

$\begin{array}{lr}\text { Received: April 10,2018 Accepted: April 30, } 2018 \quad \text { Online Published: May 23, } 2018 \\ \text { doi:10.5539/ijel.v8n5p63 } & \text { URL: https://oi.org/10.5539/ijel.v8n5p63 }\end{array}$

If liberty and equality, as is thought by some are chiefly to be found in democracy, they will be best attained when all persons alike share in the government to the utmost.

Aristotle (384 BC-322 BC), Politics

\begin{abstract}
Nativism is conceptually different from xenophobia. A xenophobe is not necessarily a nativist. Nativism can broadly mean binarism and racism together. This study traces the history of American politicians' nativist rhetoric and its reflection on the life of the immigrants. In the United States, nativism has largely been a part of the leaders' political and cultural agendas and motivated the Black-White racial binarism. Moreover, nativism continues to second this binarism and secure it from criticism by projecting it as a high level of nationalism. This paper investigates, firstly, how the nativist speech influences common man; and secondly, how the life of the immigrants is affected by this discourse. This study contrasts with many dominant theories, which hypothesize that American political discourse is controlled by the elites and directed by their nativist agendas. This study, however, finds that American political discourse is subject to the nativist pride of common white citizens who share this anima with the elites.
\end{abstract}

Keywords: election, immigrants, minorities, nativism, political discourse

\section{Introduction and Theoretical Framework}

Literary scholars often quote the remarks of George Bernard Shaw (1856-1950) about election that "democracy substitutes election by the incompetent many for appointment by the corrupt few" (1903: 228) or the view of Benito Mussolini (1883-1945) that "democracy is beautiful in theory; in practice it is a fallacy" (Mussolini, The New York Times. 1928). (Note 1) What is the truth in Shaw's view and in Mussolini's letter he wrote to the New York Times in 1928? The early contemporary scholarship of thought regards the American elections as a big event in which teams of politicians offer freedoms for salves' owners forgetting the paramount goals of equality declared in election campaigns. Francesco Trebbi, Philippe Aghion \& Alberto Alesina give a brief description to the present status of the minorities in American elections:

...electoral institutions were irrelevant in determining the level of control of the white majority: a level of control that was almost absolute. The Voting Rights Act allowed racial minorities to enter into the political arena. The white majorities reacted, within the legal boundaries of the Voting Rights Act, by changing electoral rules as to minimize expected minority influence. (2008, p. 40).

The United State has long been one of the most popular destination of international migrants attracting around 22 percent of world immigrants and cultural minorities who constitute an increasing segment of the American society. According to the Migration Policy Institute, the immigrant population hit the highest record in 2014 reaching 42.4 million immigrants of the total population (Zong \& Jeanne, 2015). The United States grants every year more than 1.2 million legal permanent residence (LPR) for people "who have a close family relationship with a U.S. citizen or LPR, needed job skills, refugee or asylee status, or who are from countries with relatively low levels of immigration to the United States" (Monger, 2009, p. 1). Though, the country has an attractive policy for immigration, it sometimes shows a strange and ambivalent attitude toward immigrants and adopts a 
fluctuating policy. This changing approach in immigration policy is attributed to factors such as illegality of immigration, negative impacts on the economy, change of the social fabric of society and security issues.

This cultural diversity of the American society does not necessarily force American politicians and parties' candidates to attract the voters of all races through demolishing cultural barriers and loathing the racial differences. The recent years witness racial classification of immigrants and minority groups by high rank officials and presidential candidates. This rising binarism is an accumulation of issues such as obsession with the major issue of homeland security especially after 9/11 terrorist attacks on New York and Washington and the increasing scale of illegal immigration. Human rights' laws concerning minorities, classes and ethnicities such as Voting Rights Act adopted in 1870 along with the several amendments concerning them had granted rights and privileges to the minorities century and half ago: "The right of citizens of the United States to vote shall not be denied or abridged by the United States or by any state on account of race, colour, or previous condition of servitude" (Amendment XV, 1870, p. $1 \&$ 2). These laws are the immigrants' assistance for assimilation and the way for embracing the culture of the new homeland. They also represent a significant dimension of the US policy in incorporating the immigrants through banning racial discrimination. These reforms have a long history of comprehensive and successful steps that comprise several amendments to the (INA) Immigration and Nationality Act and become the major revisions in American laws of nationality and naturalization.

American Election has been playing an important role in fostering racial attitude towards minorities, especially during election campaigns. Further, with reference to aforementioned views, one can easily see how candidates' racial goals become a tool to sway public and make them agitate multiculturalism: "Race is a defining factor in the way our society is structured and in the way our elections and politics are contested. Our racial inequities are wide and deep, yet our solutions are few and far between" (Rinku \& Terry, 2009, p. 5). Caitlin E. Dwyer, Daniel Stevens, John L. Sullivan and Barbara Allen believe that American election campaigns using racial messages are the most successful because most of the voters fail to recognize them as being about race $(2009$, p. 226). Racism is set to play an important role in determining the policies of political parties who are naturally accountable for Candidates' rhetoric that places the US on the path of classism and leads to more reinvigorating of prejudices against people belonging to smaller social groups.

The 9/11 events, though carried out by a small fraction of immigrant group, brought serious restrictions and amendments to American policy toward immigrants (Laque, 2010, p. 29). The events brought a seismic effect on immigration represented by the security tasks of the Department of Homeland Security, a new department created after the $9 / 11$ terrorist attacks "to develop and coordinate the implementation of a comprehensive national strategy to secure the United States from terrorist threats or attacks... and detect, prepare for, prevent, protect against, respond to, and recover from terrorist attacks within the United States" (Alperen, 2011, p. 24). The DHS works with national agencies in order to "facilitate the exchange of information among such agencies relating to immigration...coordinate efforts to investigate terrorist threats and attacks within the United States; and coordinate efforts to improve the security of United States" (Harris \& Daniel, 2009, p. 433). This new policy resulted in an explicit rise of racism, suspicion and even physical assaults on immigrants. Of course, Arab immigrants and people who look like the Muslims such as the Sikhs have become the most targeted and suspected category among immigrant groups (Harper and Kelly, 2016, p. 253). This conflation of immigrants with terrorism is well stated by the former Attorney General John David Ashcroft who summarizes the future American approach to the issue of immigration:

If you overstay your visa-even by one day-we will arrest you. If you violate a local law, you will be put in jail and kept in custody as long as possible. We will use every available statute. We will seek every prosecutorial advantage. We will use all our weapons within the law and under the Constitution to protect life and enhance security for America (Jackson, 2005, p. 202).

\section{Thesis Statement}

This study hypothesizes that election campaigns invest the racial makeup of the American society to influence the voting behaviors of the American public. Presidential Candidates exert to reinforce and disrupt the racial rubric through the magnitude of the nativist speeches during the campaigns. This study addresses two research queries. First, do Candidates' behaviours likely reinforce nativism through exaggerating threats like immigration, unemployment and homeland security? Second, does the magnitude of political speeches have effect on the life of immigrants?

\section{Election and Neo-racism}

Though many studies assume that post law amendments concerning minorities and immigrants witness gradual improvements in the social aspect, implying that major parties vying for presidency try to fulfill promises with a 
keen eye for social justices. This study, however, considers these assumptions unrealistic. This study assumes a "common agreement spot" among major parties on minorities' issues where voters are unconscious of this commonality of attitude. This study assumes that race has always played an important role in American elections (e.g. George Bush's election in 1992, Barack Obama's election in 2008 and re-election in 2012, Donald Trump's election in 2016). Race is set to play an important role by Parties' Candidates though their Parties release absolution from political racism. This study investigates the relationship between election and culture in order to understand the hidden agenda of the major parties towards minorities.

The United States Presidential election of 2016 has led to racial divide in the U.S. and resulted in big volumes of dangerous statements on immigrants and minority groups. In November 2016, in a callback survey of registered voters who voted in the election, $46 \%$ said they thought the 2016 would result in the worst race relations within the society and would increase the negative opinions of the whites on other minorities. The world media has reported the Republican support for the notion of 'Nativist Mastership' that encourages the white superiority which is better known as 'official Racism' or 'Neo-racism' against people of different colours, ethnic background and cultural affiliations. These categories have been targeted by Donald Trump who frequently calls for mass deportation of immigrants living in the United States and ending the automatic American citizenship given for foreign children born in America. Trump often goes against the American birth-right citizenship: "They [immigrants] have to go...What they're doing, they're having a baby. And then all of a sudden, nobody knows...the baby's here" (Braun, 2015). He brands all immigrants living inside the United states as opportunist who exploit the country, not as humans who are either highly skilled or who seek refuge from wars and conditions created the imperial powers. In many interviews, Trump gives a clear vision of the future policy of the American administration: "We have to start a process where we take back our country. Our country is going to hell...I don't think they have American citizenship...you're going to find they do not have American citizenship" (O’Reilly, 2015).

Nativism is a term used by critics and scholars to explain discrimination, hostility and racism against immigrants and minority groups on the grounds of the superiority of the natives. Hostility toward new arrivals has long been a serious issue arousing the Americans' inflammatory feelings and xenophobic attitudes since the colonial times. This nationalist feeling, according to John Higham (1992), gave a rise to unreasonable dislike and "intense opposition to an internal minority on the ground of its foreign (i.e. un-American) connections" (1992, p. 4). Higham, a scholar of American culture, criticizes American nativism and considers it "an inflamed and nationalistic type of ethnocentrism" (2000, p. 330). It is, therefore, a nationalism mingled with xenophobic attitude. This conglomeration of feelings and beliefs results in nativism or "an ideology, which holds that states should be inhabited exclusively by members of the native group (the nation) and that non-native elements (persons and ideas) are fundamentally threatening to the homogeneous nation-state" (Mudde, 2007, p. 19). Though major American parties highlight the importance of equality and look at election as a sanctuary from these nativist injustices against immigrants and a saviour of world social equality, Candidates' speeches are sometimes racist, hateful and narcissistic.

Historically, American nativism has been wedded to politics and ethnic agenda since the independence of the country. Nativist objection to cultural diversity in the seventeenth century political scenario, when the colonizer sought to increase the small population of the country by encouraging more immigrants from European countries, was the earliest nativist attitude yet vehement. The Declaration of Independence that announced the independence of thirteen American colonies on July 4, 1776 complained that King George III of England wanted to invite European settlers, a policy that would limit the free movement of the Anglo-Saxons who desired to populate the lands:

He [King George III] has endeavoured to prevent the population of these States; for that purpose obstructing the Laws for Naturalization of Foreigners; refusing to pass others to encourage their migrations hither, and raising the conditions of new Appropriations of Lands...He has excited domestic insurrections amongst us, and has endeavoured to bring on the inhabitants of our frontiers, the merciless Indian Savages, whose known rule of warfare, is an undistinguished destruction of all ages, sexes and conditions.... (Declaration of The Thirteen United States of America, p. 1776).

This early attitude was stated by Thomas Jefferson who wrote the American Declaration of Independence in 1776. It is also reflected in the policy of the Nation's father George Washington who wrote in 1783 that Indians "were wolves and beasts who deserved nothing from the whites but 'total ruin"” (qtd. Stannard, 1992, p. 240-41). In 1779, George Washington ordered General John Sullivan to attack the Iroquois, Haudenosaunee, an important and powerful northeast native group known as Iroquois Conferdacy. He instructed Sullivan to "lay waste all the settlements around...that the country may not be merely overrun but destroyed," commanding him not to "listen 
to any overture of peace before the total ruin of their settlements is effected" (Stannard, 1992, p. 119). This discourse towards the indigenous groups grew up as a radicle ideology and spread in the society to even dominate the well-educated elites of Harvard University. In 1894, the three Harvard alumni Charles Warren, a lawyer, Robert DeCourcy, a climatologist, and Prescott F. Hall, an attorney, founded the Immigration Restriction League (IRL) in Boston and later this league had branches in Chicago, San Francisco and New York which attracted eminent academic elites and public figures. This notable class of the society believed that people who came from southern and eastern parts of Europe were inferior to the Anglo-Saxons and therefore, the league's efforts projected a literacy test to hinder the coming of an "alarming number of illiterates, paupers, criminals, and madmen who endangered American character and citizenship" (Higham, 1988, p. 103). The second object in the IRL's constitution states that the league was founded to "advocate and work for the further judicious restriction or stricter regulation of immigration...to arouse public opinion to the necessity of a further exclusion of elements undesirable for citizenship" (Miletić, 2012, p. 49).

Since the 1980s, there has been a steady growth of xenophobia and racism in western political discourse particularly in the United States, Australia, French and England due to the rise of the populist right wings. Klaus Von Beyme describes the policies of these populist parties as a "third wave" of "right-wing extremism" which emerges as a response to the mass immigration to these countries. (1988, p. 14). According to him, this wave of parties has common fear of immigration and shares a near-pathological feature of nationalism, its roots in fear and hatred of the Other, and its affinities with racism. Roger Eatwell notes that populist parties are based on a kind of nationalist ideology which is "often expressed through a demonization of the 'Other' as much as by a precise definition of the sacred homeland" (2000, p. 412). In both Europe and the United States nativist ideologies have been successful in post-war period "in both an electoral and ideological sense, for right-wing extremist parties almost everywhere" (Mudde, 1996, p. 229). Resurgence of American nativism indicates that elections and the agendas of the parties do not normalize cultural diversity and encourage harmony in the society. World scholars believe that the 2016 election campaign has introduced the toughest rhetoric on immigrants and predict an invisible future for immigrants: "Trump has spoken of deporting millions of Latino immigrants...banning Muslim immigrants and even killing the families of Islamist terrorists. He has also called Mexican immigrants "rapists" and drug dealers" (Costello, 2016, p. 5).

The political discourse of the Republican Party becomes the incarnation of long-standing strands in US nativist attitude and an active actor in the racial polarizing issue that reinvigorates serious social divide. The House Immigration Reform Caucus (IRC) which puts tough restrictions on immigration is usually referred to as "the most prominent organization of anti-immigration politicians" (Mudde, 2012, p. 8). The IRC is founded by the Republican Cong. Tom Tancredo in 1999 to attest "the rising strength of immigration restrictionism" (Immigration Reform Caucus, 2007). Brian Bilbray, a Republican Cong, who has succeeded Tancredo as caucus chairman of IRC, defines the IRC as "an organization dedicated towards identifying legislative solutions to address the issue of illegal immigration" (IRC, 2007). This ethnic-based policy has contoured the Republican policy towards immigrants. It even plays a decisive role in shaping the Party's ethnic and socioeconomic structure, reflecting the racial biases that permit exclusions of minorities led by the ethnically dominant whites.

Immigrants represent a hot-button issue for the Republicans who usually keep immigration issue on the attack agenda (Vanessa Williamson, Theda Skocpol, and John Coggin, 2011, p. 26). The 2016 election and political discourse has swayed the electorate and encouraged nativist sentiment and expressed "a growing distrust of the immigrants already in the country and a strong desire to tighten laws that would keep others out" (Alvarez \& Tara 2000, p. 168). On March 1, 2016, Martin Wolf, the Financial Times Columnist describes winning the election by the Republicans as "global disaster" calling Donald Trump "a promoter of paranoid fantasies, a xenophobe and an ignoramus" (Financial Times 2016). Wolf goes on describing the Republican Candidate as a "grossly unqualified for the world's most important political office" and a man who hastens the collapse of the American empire: "American 'Caesarism' has now become flesh. It seems a worryingly real danger today" (2016). Joel Simon believes that American election discourse in 2016 was "insulting" and engaged in "shocking behaviour" (Simon, 2016). In electoral studies, scholars argue that race is an important factor in voting behavior in which voters show affinity with the candidate. In 2016 presidential election, Trump explicitly portrays his people as victims of the evil people and addresses their nativist emotions to get collective response:

Our country has to toughen up, folks. We have to toughen up. These people are bringing us down...These are not good people. These are not the people that are going to make our country great... These are the people that are destroying our country...These people are so bad for our country, you have no idea, folks. You have no idea. They contribute nothing, nothing...get him out, troublemaker. Hurting this country, folks. Hurting this country (Uechi, 2016). 
A wide spectrum of politicians and thinkers has to face this neo-nativist discourse and policies towards immigrants which have colored most of the media talks and common-man discussions and encouraged racial and ethnical differences. In New Hampshire, for example, Trump developed a strong dogmatic and racial sentiment when he avoided correcting one statement given by one of his fans who said "[w]e have a problem in this country, it's called Muslims. Our current President is one" (Schleifer, 2015). Trump rather supported this view by a more racist answer saying "[t]he bigger issue is that Obama is waging a war against Christians in this country. Christians need support in this country. Their religious liberty is at stake" (Johnson, 2015). The role played by nativist politics, according to Michael Barone has become "an example of the role of ethnicity in American politics" which he believes "should not play any role in politics" (2002, p. 343). Bernie Sanders who is a Jew and whose culture has long been in rivalry with the Muslims, calls for an end to the the anti-Muslim rhetoric encouraged by the Republicans. According to him, Trump's statements are ideological and people like him are "demagogues" who are once again attempting to divide us up in xenophobic and racist ways...They want us to believe the average Muslim is a terrorist (Mangla, 2015). In his answer to a comment raised by a Muslim student in a headscarf describing herself as "an American Muslim student who aspires to change this world" (Epstein 2015), Sanders gave a long and detailed answer:

Let me be very personal here, if I might, I'm Jewish. My father's family died in concentration camps. I will do everything that I can to rid this country of the ugly stain of racism which has existed for far too many years... Our job is to build a nation in which we all stand together as one people...And you are right. There is a lot of anger being generated, hatred being generated against Muslims in this country...There is hatred being generated against immigrants in this country...And if we stand for anything, we have got to stand together and end all forms of racism (Epstein, 2015).

The 2016 election's result is attributed to the populist discourse, albeit the declared efforts to secure the minorities' ethical, social, linguistic and religious rights; obfuscating the propagated notions of "idealism" and "capitalism": "They're taking our jobs. They're taking our manufacturing jobs. They're taking our money. They're killing us...we'll take our country back" (Walker, 2015). This attitude is perceived by many Americans as "a recipe for social disaster in the coming generation" (Ehrenfreund, 2015). In an interview with Patricia Lombroso, Noam Chomsky states with a terrifying clarity: "The risks are very serious. If the comments of the Republican leaders vying for the presidency correspond to the reality of the future White House, we should expect a real disaster" (Lombroso, 2016). Barack Obama had challenged the rising anti-immigrants' behaviors among the Republican supporters in 2008 and 2012 elections. In his 2008 campaign, Obama accused Rush Limbaugh and Lou Dobbs of agitating hatred against immigrants and spreading xenophobic feelings. According to Obama, "a certain segment has basically been feeding a kind of xenophobia" and "[t]here's a reason why hate crimes against Hispanic people doubled last year" (Navarrette, 2008). According to Martin Wolf:

...this is not just about a party, but about a great country. The US is the greatest republic since Rome, the bastion of democracy, the guarantor of the liberal global order (2016).

It would be a mistake to isolate candidates' discourse from the mainstream political discourse. Anxieties from the Muslims immigrants have been aggravated by the accumulated policies of the parties that started in 2001 and affected the position of the Muslim immigrants. In 2001, for example, George W. Bush declared Crusades on the Muslims, in general: "This crusade, this war on terrorism is going to take a while." (Note 2) This Crusadic language has reference to the longest Christian military attacks on the Muslim East in the $11^{\text {th }}, 12^{\text {th }}$ and $13^{\text {th }}$ Centuries and evokes collective memories of the centuries-old and centuries-long Christian invasion of Muslim Arabia. On September 11, former Republican Secretary of State Lawrence Eagleburger, who served under president George W. Bush, advises the American administration: "[t]here is only one way to begin to deal with people like this [Muslim world], and that is you have to kill some of them even if they are not immediately directly involved in this thing" (Fairness \& Accuracy in Reporting, 2001). Similarly, Ann Coulter who was raised in a conservative Republican family was even more radical in his reactions: "This is no time to be precious about locating the exact individuals directly involved in this particular terrorist attack...We should invade their countries, kill their leaders and convert them to Christianity" (2001). This attitude toward the Muslims has driven most of the white population to a racial point where all Muslim immigrants are assaulted, harassed or at least suspected.

\section{Conclusion}

One of the persistent critical inquiry, from the perspective of this study, was whether American political discourse intensifies the existed racism and proliferate ethnic inequalities that prevailed for centuries. The other issue of this research was that American politicians are unlikely to redress the variance in the moral and 
socioeconomic status of the immigrants. The study finds that, from a distance of three centuries and half, the nativist perception of the immigrants had been disenfranchising minorities on the basis of race, ethnicity and geography. Though, Human Right Acts related to immigrants, electoral reforms and the Voting Rights Acts are good efforts for improving immigrants' rights and legal status, this study, however, asserts that nativist accountability stipulates that minorities are entitled to the minimum access of rights. Recent nativist discourse during the 2016 election campaigns shows that the white majority adopts an intensified racial discourse and succeeds in widening the disparity gap between the different component of the society. This evidence shows that nativist and political discourse adopted by political institutions is influencing the voters and individual behavior who will sway the election. The study suggests that a wide spectrum of national reactions is needed to play a pivotal role not only in the future of the immigrants but also in world politics and global stability.

\section{Acknowledgment}

The authors acknowledge the financial support of this study under the grant no. 6926-EAR-2017-1-7-F from the Deanship of Scientific Research at Northern Border University, Arar, KSA.

\section{References}

Alperen, M. J. (2011). Foundations of Homeland Security: Law and Policy. New Jersey: Wiley \& Sons INC.

Alvarez, R. M., \& Tara, L. B. (2000). The Resurgence of Nativism in California? The Case of Proposition 187 and Illegal Immigration. Social Science Quarterly, 81(1), 167-179.

Barone, M. (2002). Race, Ethnicity, and Politics in American History. In A. Thernstrom \& S. Thernstrom (Eds.), Beyond the Color Line New Perspectives on Race and Ethnicity in America (pp. 343-58). Stanford University Stanford, California: Hoover Institution Press.

Beyme, K. V. (1988). Right-wing Extremism in Post-war Europe. West European Politics, 11(2), 1-18. https://doi.org/10.1080/01402388808424678

Braun, S. (2015). Trump: All immigrants living in the US illegally 'have to go' — and so do their children. Retrieved from http://www.businessinsider.com/trump-all-immigrants-living-in-the-us-illegally-have-to-go-2015-8

Costello, M. B. (2016). The Trump Effect: The impact of the presidential campaign on our nation's schools. Alabama: Southern poverty Law Centre.

Dwyer, C. E., Daniel S., John L. S., \& Barbara A. (2009). Racism, Sexism, and Candidate Evaluations in the 2008 U.S. Presidential Election. Analyses of Social Issues and Public Policy, 9(1), 223-240. https://doi.org/10.1111/j.1530-2415.2009.01187.x

Eatwell, R. (2000). The Rebirth of the 'Extreme Right' in Western Europe. Parliamentary Affairs, 53(3), 407-25. https://doi.org/10.1093/pa/53.3.407

Ehrenfreund, M. (2015). Understanding Trump's plan to end citizenship for undocumented immigrants' kids. Retrieved from https://www.washingtonpost.com/news/wonk/wp/2015/08/17/understanding-trumps-plan-to-end-citizenship -for-undocumented-immigrants-kids/

Epstein, K. (2015). Muslim advocates welcome Bernie Sanders' support but want visible action. Retrieved from https://www.theguardian.com/us-news/2015/nov/02/muslim-american-groups-bernie-sanders-islamophobia

Fairness \& Accuracy in Reporting. (2001). Media March to War. Retrieved from http://fair.org/press-release/media-march-to-war/

Harper, D. W., \& Kelly, F. (2016). Crime and Criminal Justice in Disaster. Durham, North Carolina: Carolina Academic Press.

Harris, R. A., \& Daniel, J. T. (2009). A History of the U.S. Political System: Ideas, Interests, and Institutions. Santa Barbara, California: ABC-CLIO.

Higham, J. (1992). Strangers in the Land: Patterns of American Nativism, 1860-1925. New Brunswick, N.J.: Rutgers University Press.

Higham, J. (2000). Instead of a Sequel, or How I Lost My Subject. Reviews in American History, 28, 327-339. $10.1353 /$ rah.2000.0033

Higham, J. (Ed.). (1988). Strangers in the Land: Patterns of American Nativism, 1860-1925. New Brunswick: Rutgers University Press. 
House Immigration Reform Caucus (IRC). (2007). Home: Immigration Reform Caucus. Retrieved March 30, 2017, from www.house.gov/bilbray/irc

Jackson, R. (2005). Writing the War on Terrorism: Language, Politics and Counter-terrorism. Manchester: Manchester University Press.

Johnson, J. (2015). Trump doesn't correct rally attendee who says Obama is Muslim and not even an American. Retrieved September 17, 2017, from http://www.washingtonpost.com/news/post-politics/wp/2015/09/17/trump-doesnt-correct-rally-attendee-wh o-says-obama-is-muslim-and-not-even-an-american/

Laque, E. C. (2010). Immigration Law and Policy: Before and After September 11, 2001. Social Sciences Journal, 10(1), 24-34. https://repository.wcsu.edu/ssj/vol10/iss1/10

Lombroso, P. (2016). Republicans are a danger to the human species. Interview with Noam Chomsky. Retrieved April 25, 2017, from http://ilmanifesto.global/chomsky-republicans-are-a-danger-to-the-human-species/

Mangla, I. (2015). Bernie Sanders Visits DC Mosque, Blasts Trump for 'Bigotry' Against Muslims. Retrieved April 15, 2017, $\quad$ from www.ibtimes.com/bernie-sanders-visits-dc-mosque-blasts-trump-bigotry-against-muslims-2229162_

Mendelberg, T. (2001). The Race Card. Princeton: Princeton University Press.

Miletić, A. R. (2012). Journey under Surveillance: the overseas emigration policy of the Kingdom of Serbs, Croats and Slovenes in global context: 1918-1928. Munster: LIT Verlag.

Monger, R. (2009). U.S. Legal Permanent Residents. Department of Homeland Security. Retrieved September 20, 2017, from https://www.dhs.gov/sites/default/files/publications/lpr_fr_2009.pdf

Mudde, C. (1996). The war of Words Defining the Extreme Right Party Family. West European Politics, 19(2), 225-249. https://doi.org/10.1080/01402389608425132

Mudde, C. (2007). Populist radical right parties in Europe. Cambridge: Cambridge University Press.

Mussolini, B. (1928). To Edwin L james. Retrieved July 13, 2017, from http://fridayfiveblog.blogspot.com/2010/09/us-tea-party-and-spectre-of-fascism.html

Navarrette, R. (2008). Dobbs, Limbaugh feed hate of Latinos. Tucson Citizen. Retrieved July 12, 2017, from http://www.latinamericanstudies.org/immigration/dobbs-limbaugh.htm

Novick, M. (2016). A Post-Mortem on Post-Election Post-Mortems: The Death Knell of White Supremacy. Retrieved July 13, 2017, from https://awarela.files.wordpress.com/2008/05/in-response-to-donald-trump-statement.pdf

O'Reilly, B. (2015). Donald Trump's immigration plan. FoxNews.com. Retrieved July 19, 2017, from http://www.foxnews.com/transcript/2015/08/19/donald-trump-immigration-plan/

Rinku, S., \& Terry K. (2009). Preface. In L. Burnham (Ed.), Changing the Race: Racial Politics and the Election of Barack Obama. Oakland: Applied Research Center.

Schleifer, T. (2015). Trump doesn't challenge anti-Muslim questioner at event. Retrieved June 11, 2017, from http://edition.cnn.com/2015/09/17/politics/donald-trump-obama-muslim-new-hampshire/

Shaw, G. B. (1903). Man and Superman. Westmister: Archibald Constable and Co. ltd.

Simon, J. (2016). Why journalists should be afraid of Trump's media strategy. Colomibia Retrieved June 11, 2017, from www.cjr.org/first_person/why_journalists_should_be_afraid_of_trumps_media_strategy.php

Stannard, D. E. (1992). American Holocaust: The Conquest of the New World. New York: Oxford University Press.

Trebbi, F., Philippe A., \& Alberto A. (2008). Electoral Rules and Minority Representation in U.S. Cities. Quarterly Journal of Economics, 123(1), 325-357. https://doi.org/10.1162/qjec.2008.123.1.325

Uechi, J. (2016). Videos show Trump goading his fans to "rough up" protesters by Jenny Uechi in News. Retrieved April 10, 2017, from www.nationalobserver.com/2016/03/13/news/videos-suggest-trump-goaded-his-fans-rough-protesters

US National Archive. (1776). Declaration of Independence: A Transcription. IN CONGRESS, July 4, 1776. Retrieved April 11, 2017, from www.archives.gov/exhibits/charters/declaration_transcript.html 
US National Archives. AMENDMENT XV.1\&2. (1870). The Constitution: Amendments 11-27. Retrieved April 25, 2017, from http://www.archives.gov/exhibits/charters/constitution_amendments_11-27.html

Walker, H. (2015). Donald Trump just released an epic statement raging against Mexican immigrants and $\begin{array}{lllll}\text { 'disease'. } \quad \text { Retrieved 2017, } & \text { March } & \text { from }\end{array}$ http://www.businessinsider.com/donald-trumps-epic-statement-on-mexico-2015-7

Williamson, V., Theda, S., \& John, C. (2011). The Tea Party and the Remaking of Republican Conservatism. Perspectives on Politics, 9(1), 25-43. https://doi.org/10.1017/S153759271000407X

Wolf, M. (2016). Donald Trump embodies how great republics meet their end. Retrieved September 2, 2217 , from https://segundavueltasv.wordpress.com/2016/03/20/tres-columnas-desnundando-a-donald-trump/

Zong, J., \& Jeanne, B. (2016). Frequently Requested Statistics on Immigrants and Immigration in the United $\begin{array}{lllll}\text { States. } & \text { Retrieved } & \text { September } & \text { 2017, } & \text { from }\end{array}$ http://www.migrationpolicy.org/article/frequently-requested-statistics-immigrants-and-immigration-unitedstates

\section{Notes}

Note 1. Benito Mussolini's Letter to Edwin L James of the New York Times in 1928: 'Democracy is talking itself to death. The people do not know what they want; they do not know what is the best for them. There is too much foolishness, too much lost motion. I have stopped the talk and the nonsense. I am a man of action. Democracy is beautiful in theory; in practice it is a fallacy. You in America will see that someday'. A transcript is available at: http://fridayfiveblog.blogspot.com/2010/09/us-tea-party-and-spectre-of-fascism.html

Note 2. On September 12, 2001, Mr. Bush addressed the nation "But we need to be alert to the fact that these evil-doers still exist. We haven't seen this kind of barbarism in a long period of time. No one could have conceivably imagined suicide bombers burrowing into our society and then emerging all in the same day to fly their aircraft-fly U.S. aircraft into buildings full of innocent people — and show no remorse. This is a new kind of - a new kind of evil. And we understand. And the American people are beginning to understand. This crusade, this war on terrorism is going to take a while. And the American people must be patient. I'm going to be patient." A transcript is available at: https://georgewbush-whitehouse.archives.gov/news/releases/2001/09/20010916-2.html

\section{Copyrights}

Copyright for this article is retained by the author, with first publication rights granted to the journal.

This is an open-access article distributed under the terms and conditions of the Creative Commons Attribution license (http://creativecommons.org/licenses/by/4.0/). 